\title{
THE FIRST HIRNANTIAN (UPPERMOST ORDOVICIAN) ODONTOPLEURID TRILOBITE FROM WESTERN GONDWANA (ARGENTINA)
}

\author{
KAREN HALPERN, JUAN JOSÉ RUSTÁN \& FACUNDO RENÉ MEROI ARCERITO \\ Centro de Investigaciones Ciencias de la Tierra, CONICET y Universidad Nacional de Córdoba. \\ Av. Vélez Sarsfield 1611, X5016GCA, Córdoba, Argentina. karenhalpern@gmail.com, \\ juanjorustan@gmail.com,facundomeroi@hotmail.com
}

\begin{abstract}
An odontopleurid trilobite remain is described for the first time from Hirnantian (uppermost Ordovician) rocks of Western Gondwana. Very rare material, represented by a single left librigena, comes from a new fossil locality of the Don Braulio Formation in the Eastern Argentine Precordillera. Based on an updated systematic discussion, the fossil is tentatively referred to Eoleonaspis Sheng. Environmental and paleogeographical settings of this finding suggest that the genus would be eurytopic, having a cosmopolitan geographical distribution during the Ordovician-Silurian interval. In addition, the new evidence reinforces that scarce odontopleurids, often represented by Eoleonaspis, characterize a trilobite association together with Mucronaspis Destombes, strengthening it as a worldwide Hirnantian biostratigraphic indicator.
\end{abstract}

Key words: Ordovician, Hirnantian, Argentina, Gondwana, trilobites, Eoleonaspis, Mucronaspis.

RESUMO - É descrito pela primeira vez resto de trilobita odontopleurídeo de rochas do Gondwana Ocidental (Hirnantiano, porção mais superior do Ordoviciano). O material é muito raro, representado por uma única librigena esquerda proveniente de uma nova localidade da Formação Don Braulio na Precordilheira Oriental Argentina. Com base em uma discussão sistemática atualizada, o fóssil é tentativamente referido como Eoleonaspis Sheng. Configurações ambientais e paleogeográficas deste achado sugerem que o gênero seria euritópico, tendo uma distribuição geográfica cosmopolita durante o intervalo Ordoviciano-Siluriano. Além disso, a nova evidência reforça que odontopleurídeos escassos, muitas vezes representados por Eoleonaspis, caracterizam uma associação trilobita juntamente com Mucronaspis Destombes, fortalecendo-o como um indicador bioestratigráfico mundial do Hirnantiano.

Palavras-chave: Ordoviciano, Hirnantiano, Argentina, Gondwana, trilobitas, Eoleonaspis, Mucronaspis.

\section{INTRODUCTION}

Uppermost Ordovician (Hirnantian) marine sedimentary rocks have good records throughout Western Gondwana (Astini, 2003 and references therein; Benedetto et al., 2013). Successions from this region carry evidence of a major glacial event and associated mass extinction recognized worldwide in coeval stratigraphic units. Such Hirnantian global events are well biostratigraphically based on brachiopods, graptolites, conodonts and trilobites, and include extinctions of late Katian associations and onset of nearly cosmopolitan index taxa such as the brachiopod Hirnantia Lamont, 1935, the graptolite Normalograptus persculptus (Salter, 1865) and the trilobite Mucronaspis Destombes, 1963 (Cheng, 2003).

A typical Hirnantian trilobite assemblage includes the dalmanitid trilobite Mucronaspis along with the odontopleurid Eoleonaspis Sheng, 1974. See also Congreve \& Lieberman (2008) for a discussion of other typical Hirnantian trilobites. In spite of the abundant record of Mucronaspis in well-known reported Hirnantian associations from Western Gondwana, no accompanying odontopleurids trilobites had been identified up to date.
In the particular case of the Argentine Precordillera, despite detailed investigations of Hirnantian units and intensive sampling mainly focused on the Don Braulio Formation (Hirnantian), only the trilobites Mucronaspis and Eohomalonotus Reed, 1918 had been reported (Baldis \& Blasco, 1975; Waisfeld \& Vaccari, 2003).

In this contribution, is reported an extremely rare record of an odontopleurid trilobite from the upper member Don Braulio Formation. Paleobiogeographical and biostratigraphical implications of this new finding are briefly commented.

\section{GEOLOGICAL SETTING}

The study area embraces the Villicum Ranges, a set of small mountains belonging to the Eastern Argentine Precordillera, located nearly $20 \mathrm{~km}$ to the north of San Juan city in San Juan Province, Argentina (Figura 1A). The Villicum Ranges record a thick and nearly homoclinal sedimentary succession, exhibiting an east dip, which involves a number of Paleozoic units ranging from the Cambrian to the Silurian (from west to east). In these ranges the Ordovician-Silurian boundary is recorded within the Don Braulio Formation (Baldis et al., 
1982), a thin siliclastic unit (46 m of maximum thickness at the type section of the Don Braulio Creek), which outcrops continuously for almost $3 \mathrm{~km}$ in the area. Usually the Don Braulio Formation overlies, throughout an unconformity, the La Cantera Formation (Sandbian) and underlies the Mogotes Negros Formation (Silurian). However, at other sections in the area studied, the La Pola Formation (Sandbian) overlies the La Cantera Formation and underlies the Don Braulio Formation. The Don Braulio Formation is divided in two members: the lower member is interpreted as glacial-marine diamictite deposits, and the upper member is considered as a transgressive-regressive marine sequence (see Astini \& Buggisch, 1993; Astini, 2001).

The Figure 1B shows a detailed stratigraphic column of the Don Braulio Formation at the La Pola Creek, where its features are the closest to the type section. This section was surveyed in order to correlate our fossiliferous levels, which come from an undescribed outcrop. In the La Pola Creek, the Don Braulio Formation reaches $35 \mathrm{~m}$ in thickness. The lower member begins with $8,2 \mathrm{~m}$ of a diamictite with an erosive base which bears striated, rounded and angular blocks. This basal diamictite was interpreted as deposited in a marine-glacial environment by Astini (2001), and related with the wellknown Hirnantian Gondwanan glacial event (Peralta \& Carter, 1990; Astini \& Buggisch, 1993; Astini, 2003 and references therein). The section continues with the upper member: 26,5 $m$ of a muddy platform sequence interbedded with occasional tabular and lenticular beds of sandstones. The first $5 \mathrm{~m}$ of this muddy stratigraphic interval are composed of greenish bioturbated siltstones containing sandy carbonate nodules and lenses with the trilobites Eohomalonotus and Mucronaspis (Baldis \& Blasco, 1975; Waisfeld \& Vaccari, 2003). The next $21,5 \mathrm{~m}$, consist of ocher siltstone with the first appearance of Normalograptus persculptus (see Toro \& Brussa, 2003). At the top of the succession, three beds of oolitic ferruginous sandstones occur. These beds are interpreted as shallow marine bars, and used for regional correlation (Astini \& Benedetto, 1992).

The sampling area comprises a new locality named Varves Creek section, corresponding to an undescribed isolated outcrop mainly constituted by the lower part of the Don Braulio Formation. The Varves Creek section is located at a little secondary creek, adjacent to the base of the La Pola Creek section, two kilometers to the south of the Don Braulio type section, at $31^{\circ} 13^{\prime} 22,3^{\prime \prime} \mathrm{S} / 68^{\circ} 29^{\prime} 24,5^{\prime \prime} \mathrm{W}$ (Figure 1B).

There are some stratigraphic differences between the type section, the La Pola section and the Varves Creek section. Stratigraphic sucession of the Varves Creek starts with 4 $\mathrm{m}$ of the basal diamictite, followed by a $20 \mathrm{~cm}$ layer of conglomerates. Then, almost $3 \mathrm{~m}$ of a succession of varveslike siltstones interbedded with fine sandstones beds, which were interpreted by Astini (2003) as incompletes Bouma's series. At the top of the lower part of the Don Braulio Formation, it is recognized another thin conglomerate, which most probably correlates with the ravinement surface observed in other sections at the top of the diamictite. Higher in the section, $3,8 \mathrm{~m}$ of massive greenish bioturbated siltstones continue, with two interbedded fine grained tabular sandstones. This stratigraphic interval bears typical brachiopods of the Hirnantia fauna, and also the trilobites Mucronaspis and Eohomalonotus, together with the new odontopleurid specimen.

\section{AGE OF THE FAUNA}

The fossils found in the Varves Creek Section are Hirnantian in age, based on the occurrence of trilobites constrained to the latest Ordovician, such as Mucronaspis sudamericana (Baldis \& Blasco, 1975) and Eohomalonotus villicumensis (Baldis \& Blasco, 1975), along with elements of the brachiopod Hirnantia Fauna as Hirnantia sagittifera (M'Coy, 1851), Dalmanella aff. D. testudinaria (Dalman, 1828), Paromalomena polonica (Temple, 1965) and Eostropheodonta hirnantiensis (M'Coy, 1851) (see Benedetto, 1986). In addition, $80 \mathrm{~cm}$ above the sampling point we identify the first appearance of Normalograptus persculptus which indicates the Hirnantian 2 (Hi2), according to Bergström et al. (2009).

\section{MATERIAL AND METHODS}

The new fossil locality named Varves Creek is referred to in a geologic map using GPS coordinates (Figure 1A). The stratigraphic section was surveyed in detail, sampling layer by layer (Figura 1B), yet only one odontopleurid trilobite specimen was recovered. Despite the examination of more than 1,700 specimens belonging to 34 paleontological samples housed in repository, obtained during previous field works from coeval strata of the nearly area, no additional odontopleurid specimens were identified.

The odontopleurid specimen studied is preserved in greenish-grey siltstones, mostly replaced by iron reddish oxides, and covered by a light outer carbonate coating. Associated fauna include scolecodonts, bryozoans (Helopora sp. and Phylloporinidae indet.; Carrera \& Halpern, 2011), bivalves (Modiolopsis cuyana Sanchez, 1990 and Paleoneilo sp.; Sánchez et al., 1991), gastropods (Holopea sp.; Bertero \& Halpern, 2012), graptolites, trilobites and brachiopods (mentioned above), and crinoids.

In order to obtain the external latex mould of the librigena, the sedimentary matrix was removed using pneumatic vibrators. Oxides were mechanically removed using needles, whilst carbonate material was eliminated using diluted $(10 \%)$ hydrochloric acid.

For illustrating the arrangement of the epiborder spines (preserved as reddish spots), the natural external mould was photographed in color submerged in water, and illuminated using flush lamplight (Figure 2C). The material was also stained with black paint, and then whitened with ammonium chloride sublimate (Figures 2A,B,D,E). Images were captured using a digital camera Canon Power Shot S50 mounted on a binocular magnifier Leica MZ75.

The material is housed in the paleontological collection of the Centro de Investigaciones Paleobiológicas (CIPAL) of 
the Universidad Nacional de Córdoba, Córdoba (Argentina) under repository number CEGH-UNC 25725. Morphological abbreviations: sag., sagittal/sagittally; exsag., exsagittal/ exsagittally; tr., transversal/transversely. The open nomenclature follows the criteria of Bengtson (1988).

\section{SYSTEMATIC PALEONTOLOGY}

Family ODONTOPLEURIDAE Burmeister, 1843 Subfamily ODONTOPLEURINAE Burmeister, 1843

\section{Eoleonaspis Sheng, 1974}

Eoleonaspis? sp.

(Figure 2)

Type species. Acidaspis shanensis Reed, 1915, Hirnantian of the Pangsha-pye Formation, Shan States, Burma, by original designation.

Material from Argentina. One left librigena, CIPAL, CEGH-UNC 25725.

Description. Nearly complete left librigena of sag. length about, 10,7 mm. Librigenal field gently sloping (Figures 2A,B,D) and concave, moderately narrow (tr.), evenly covered by very fine granules, and bearing coarse and scattered tubercles which have subtle associated ridges, arranged so as to weakly insinuate very faint rows nearly radiating from near the eye base (Figures 2A,B). Lateral border furrow narrow (tr.) and shallow. Lateral border weakly convex dorsally, evenly covered by fine granules and irregularly by coarser ones, bearing spiny tubercles and epiborder spines and/or tubercles of various sizes dorsally not conspicuously arranged in a regular pattern (Figure 2C). An epiborder furrow could not be identified. Lateral margin evenly curved and bearing nine preserved spines arranged in a marginal row, being progressively longer, more inclined and more separated backwards, and disposed in a same horizontal plane (in lateral view, Figure 2D). Each marginal spine moderately long, slender, pointed and bended backwards at the tip, dorsally convex and ventrally flat, slightly convex anteriorly and concave posteriorly, evenly covered by fine and irregularly distributedcoarse granules (these are more frequent and spiniform at the base of each marginal spine). Base of the genal spine (Figure 2E) relatively narrow (tr.), barely convex dorsally, bearing several dorsal spines like the lateral border; these rapidly decrease in number backwards (exsag.). Genal spine (Figure 2A) very long and narrow (tr.), narrowing evenly backwards, gently curved laterally (outwardly convex), laterally outstanding from the curvature of the lateral margin, of barely convex dorsal surface and nearly flat ventral side, evenly covered by fine granules and irregularly by scarce coarser ones especially near the base, exhibiting in the proximal quarter a large outer marginal spine similar to those of the lateral margin. Ocular area and facial sutures poorly preserved.

Remarks. According to the concept of the subfamilies Odontopleurinae and Acidaspidinae given by Ramsköld
\& Chatterton (1991, p. 357), our material is considered an odontopleurine based on the slender base of the genal spine (Figure 2E) and considerable spinosity of the exoskeleton (Figure 2C).

Latest Ordovician odontopleurine trilobites include a small group of relative genera (see Ramsköld \& Chatterton, 1991; Curtis \& Lane, 1998; Cocks \& Fortey, 2002). Among these, Kettneraspis Prantl \& Přibyl, 1949 has only been tentatively reported from Ordovician strata (e.g. Lespérance \& Weissenberger, 1998), it includes species only reliably known from the Silurian and Devonian. In addition, an emended diagnosis provided by Curtis \& Lane (1998), indicates a wide (tr.) base of the genal spine as a generic character for Kettneraspis. So that, on stratigraphic and morphological grounds, we consider that our librigena (with narrow genal spine base and certain Hirnantian age) as not belonging to Kettneraspis.

This conclusion can also be extended to Leonaspis Richter \& Richter, 1917, a Silurian-Devonian Gondwanan genus closely allied to Kettneraspis, according to the exhaustive taxonomic revision performed by Ramsköld \& Chatterton (1991). Instead, there are no morphological evidences for separating our librigena from that of the Late OrdovicianEarly Silurian genus Eoleonaspis, and putative taxa of closest taxonomic relationships (remarkably Primaspis Richter \& Richter, 1917 and Bojokoralaspis Šnajdr, 1984). Eoleonaspis was originally proposed as a subgenus of Leonaspis by Sheng (1974), and later erected as a valid genus by Ramsköld \& Chatterton (1991), but without providing a diagnosis. The generic concept was later precised by Curtis \& Lane (1998), although unfortunately without mentioning librigenal characters of taxonomic significance. In spite of this, we consider that our material most probably corresponds to Eoleonaspis because it is the odontopleurine trilobite most commonly reported from rocks of uncontroverted Hirnantian age. This trilobite, in addition, occurs typically accompanied by the dalmanitid trilobite Mucronaspis and the brachiopod Hirnantia, as in our case (see paleobiogeographical discussion below).

The generic status of Bojokoralaspis from the Ordovician of Bohemia, is rejected herein in spite of a different criterion by Shaw (2000) or Mergl (2011). Bojokoralaspis was initially postulated as subgenus of Primaspis by Šnajdr (1984), but due to the absence of consistent apomorphies, it has been steadily interpreted as junior subjective synonym of Eoleonaspis by the majority of authors up to date (Sheng, 1974; Ramsköld \& Chatterton, 1991; Curtis \& Lane, 1998; Vaněk \& Valiček, 2001; Budil et al., 2011). In contrast, taxonomic criteria for separating the very closely allied genus Primaspis (mainly recorded in the Ordovician of Bohemia) from Eoleonaspis, have been discussed at length by several authors, as it has been exhaustively summarized by Curtis \& Lane (1998). These authors focused on a series of subtle morphological differences, postulating an Ordovician-Silurian lineage involving both taxa in an ancestor-descendant relationship. However, Cocks \& Fortey (2002) called attention to Primaspis being probably paraphyletic in this proposal, thus questioning the reasons for its taxonomic recognition at generic level. This 


\section{La Pola Sur Creek}
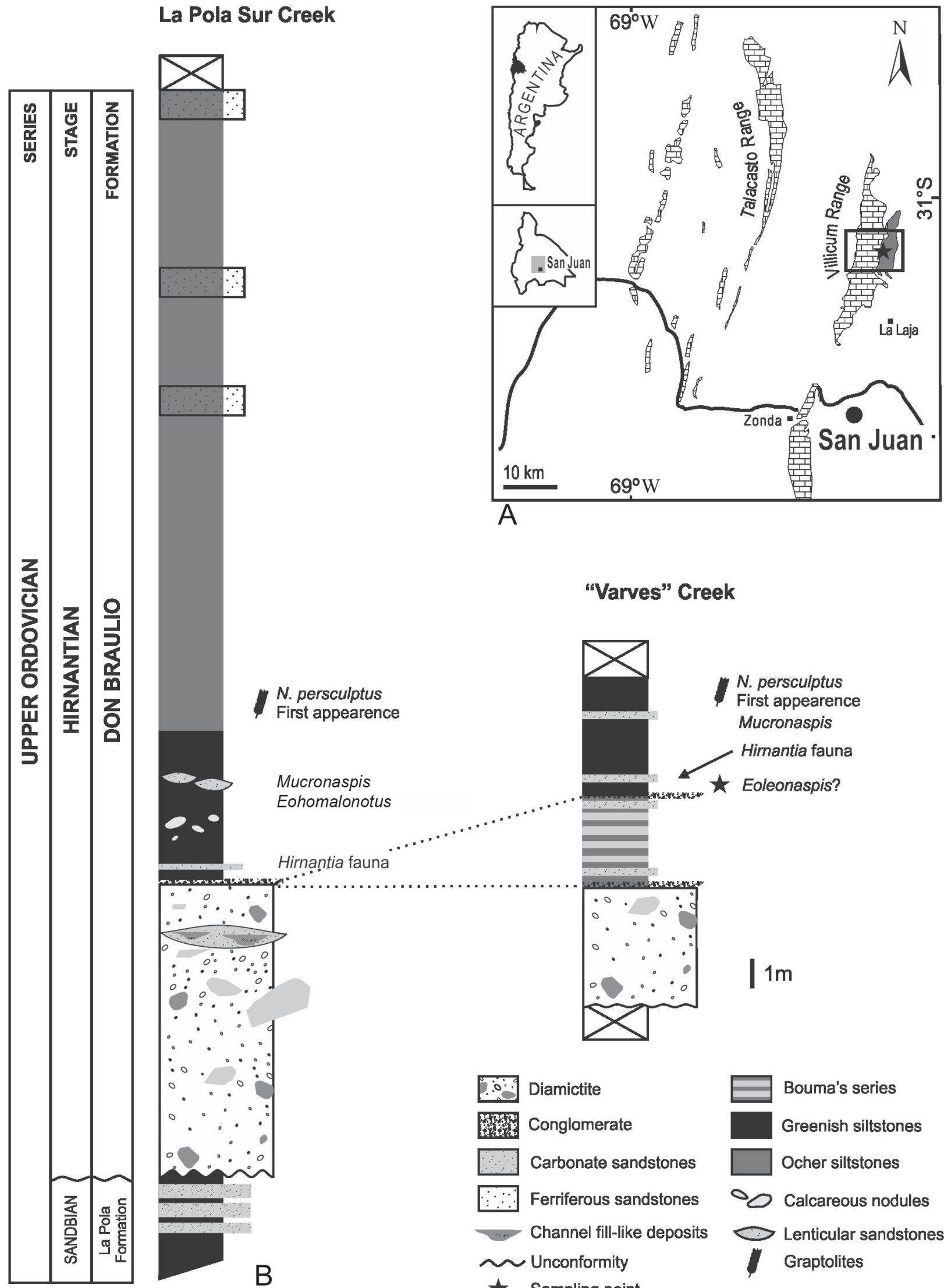

"Varves" Creek

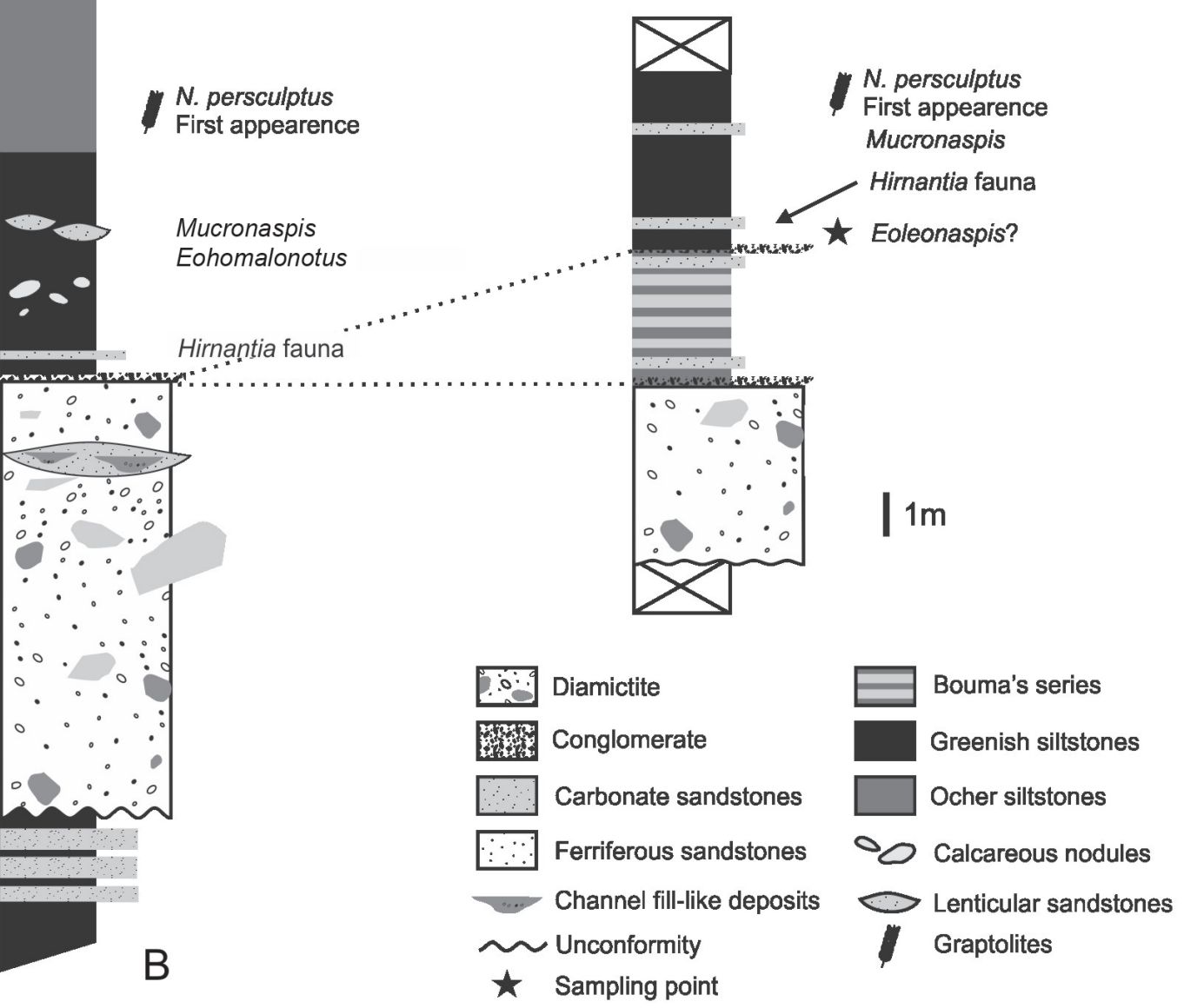

Figure 1. Geological map and stratigraphic columns of the studied area. A, geological map situating the studied sections of the Don Braulio Formation in the Argentine Precordillera; $\mathbf{B}$, stratigraphic columns of the typical section of the Don Braulio Formation at the La Pola Creek, and the new fossil locality at the Varves Creek, showing the stratigraphic levels with Mucronaspis and Eoleonaspis?. 


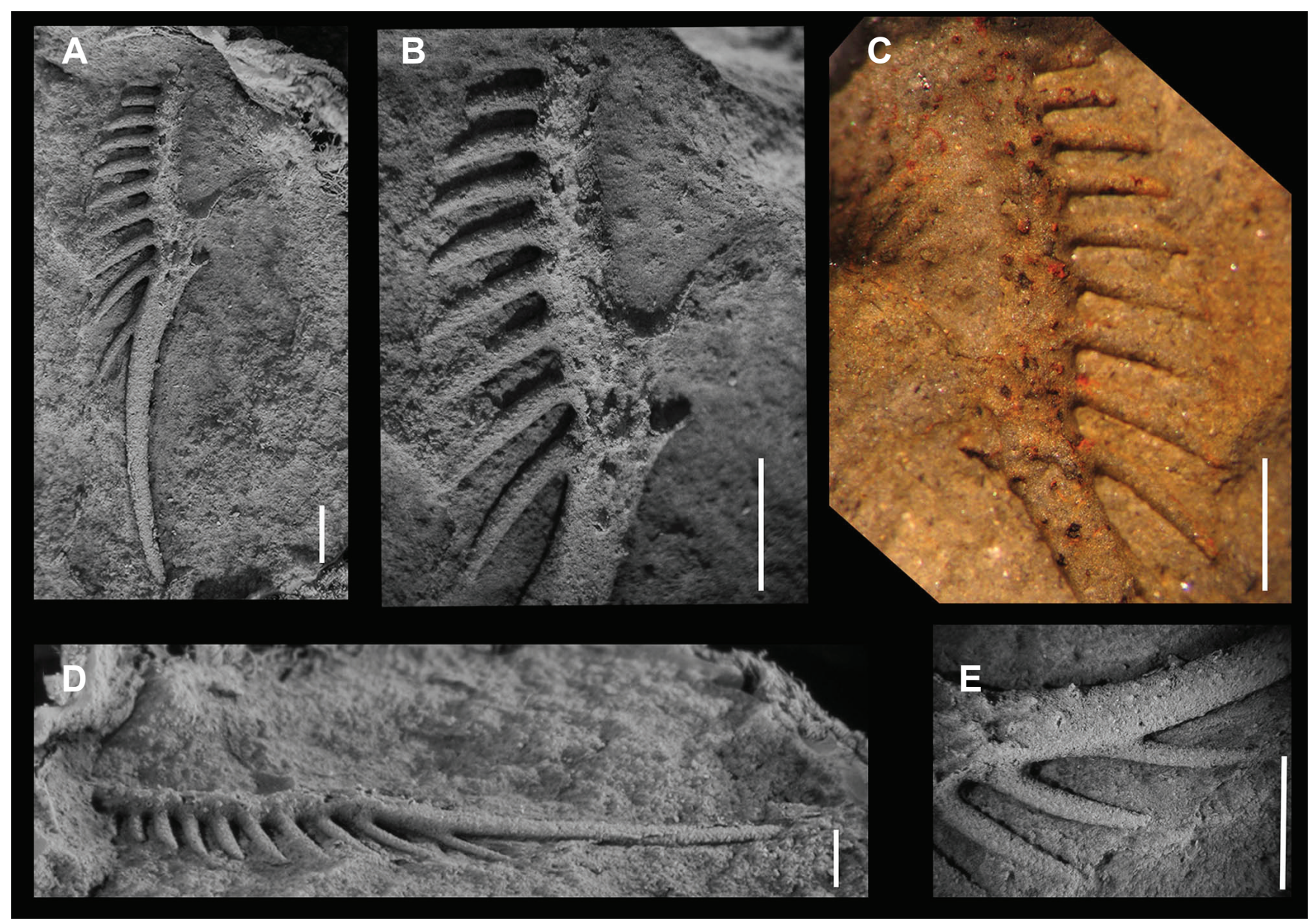

Figure 2. Eoleonaspis? sp., left librigena. A, latex mould dorsal view; $\mathbf{B}$, detail of marginal spines; C, dorsal view of the original fossil submerged under water; $\mathbf{D}$, latex mould lateral view; $\mathbf{E}$, detail of the genal spine base and associated spines. Scale bars $=1 \mathrm{~mm}$.

opinion would suggest that Primaspis should be considered as senior synonym of Eoleonaspis, pending a profound revision and cladistic analysis, like that of Ramsköld \& Chatterton (1991), which is beyond the scope of this work.

Hence, all in all, evidences indicate our material most probably corresponds to Eoleonaspis. Nevertheless, because the characters of highest taxonomic significance among commented odontopleurine taxa mainly derive from the cranidium and pygidium, this affiliation is only tentatively proposed.

\section{PALEOBIOGEOGRAPHICAL AND BIOSTRATIGRAPHICAL CONSIDERATIONS}

Most of the trilobites known for the Latest Ordovician commonly integrate highly endemic associations, constituted by relicts of earlier local faunas (Owen, 1986; Congreve \& Lieberman, 2010, 2011).

As an exception, a few cosmopolitan genera conform to a recurrent Hirnantian association (Owen et al., 1991), which is characterized by abundant dalmanitids (Mucronaspis/ Dalmanitina Reed, 1905) and homalonotids of discussed phylogenetic affinities (typically Platycoryphe Foerste, 1919/“Brongniartella" Reed, 1918 and Eohomalonotus;
Congreve \& Lieberman, 2008), usually accompanied by scarce odontopleurids (Štorch \& Mergl, 1989; Zhan \& Jin, 2007; Budil et al., 2011; Zhou et al., 2011). Within this assemblage, Eoleonaspis is the most frequent odontopleurid. Indeed, the Mucronaspis-Eoleonaspis association has been recorded in the Sibumasu plate (Cocks \& Fortey, 2002), South China plate (Zhan \& Jin, 2007; Rong et al., 2008; Zhou et al., 2012), Eastern Gondwana (Cocks \& Cooper, 2004), Laurentia (Lespérance, 1988, Owen, 1986; Wright, 1968), Perunica (Štorch \& Mergl, 1989; Ramsköld \& Chatterton, 1991), Avalonia (Ramsköld \& Chatterton, 1991) and Baltica (Ramsköld \& Chatterton, 1991), see Figure 3.

As was already mentioned, although Western-Gondwana Hirnantian stratigraphy has been thoroughly studied, no odontopleurid trilobites have been mentioned so far. Hence, Eoleonaspis seems to be restricted to low and middle latitudes, according to the paleogeographical reconstruction of Cocks $\&$ Torsvik (2002; Figure 3).

In coincidence with global patterns, the Hirnantian strata studied here contain a low diversity trilobite assemblage comprising the dalmanitid Mucronaspis and the homalonotid Eohomalonotus, as the most abundant taxa, in association with an extremely rare odontopleurid. 
Taking into account that the Argentine Precordillera was situated at higher latitudes during the latest Ordovician, probably at $45^{\circ} / 50^{\circ} \mathrm{S}$ (Benedetto, 2004; Benedetto et al., 2011), this new occurrence suggests that Eoleonaspis would have inhabited cooler waters than previously thought. In addition, according to the paleoenvironmental interpretations of the fossil-bearing beds of the Don Braulio Formation, they were developed in relatively deep siliciclastic facies, situated below the storm wave base (Sánchez et al., 1991). Hence, our evidence agrees with the idea that Eoleonaspis would be a eurytopic, widespread genus, distributed along a latitudinal gradient ranging from equatorial to peripolar regions, and dwelling in several bathymetric zones and substrate conditions. Accordingly, Eoleonaspis seems to exhibit a truly cosmopolitan distribution accompanying Mucronaspis. Here is hypothesizing that the typical absence from major Hirnantian biogeographical regions, as the Edgewood and Bani Provinces (Rong \& Harper, 1988), might be explained by its extreme rarity.

This report from the Argentine Precordillera confirms the presence of odontopleurids in Western Gondwana during Hirnantian times. Although our material is just tentatively referred to Eoleonaspis, it suggests that the MucronaspisEoleonaspis association is nearly cosmopolitan and could become a useful biostratigraphic indicator.

\section{ACKNOWLEDGEMENTS}

The authors wish to acknowledge the assistance of the Consejo Nacional de Investigaciones Científicas y Técnicas (CONICET) and the Universidad Nacional de Córdoba, both of which support facilities used in this investigation. Profoundly thanks to B. Lieberman and P. Budil for their constructive comments which improve the manuscript. This article is a contribution to IGCP 591. Thanks to C. Prestianni, P. Budil and D. Bruton for providing bibliographic material.

\section{REFERENCES}

Astini, R.A. 2001. Pavimentos estriados en la Formación Don Braulio y naturaleza de la glaciación hirnantiana (Ordovícico Tardío) en la región andina. Revista de la Asociación Argentina de Sedimentología, 8:1-25.

Astini, R.A. 2003. The Ordovician Proto-Andean Basins. In: J.L. Benedetto (ed.) Ordovician Fossils of Argentina, Secretaría de Ciencia y Tecnología/Universidad Nacional de Córdoba, p. 1-74.

Astini, R.A. \& Benedetto, J.L. 1992. El Ashgilliano tardío (Hirnantiano) del cerro La Chilca, Precordillera de San Juan, Argentina. Ameghiniana, 29:249-264.

\section{Late Ordovician $445 \mathrm{Ma}$}

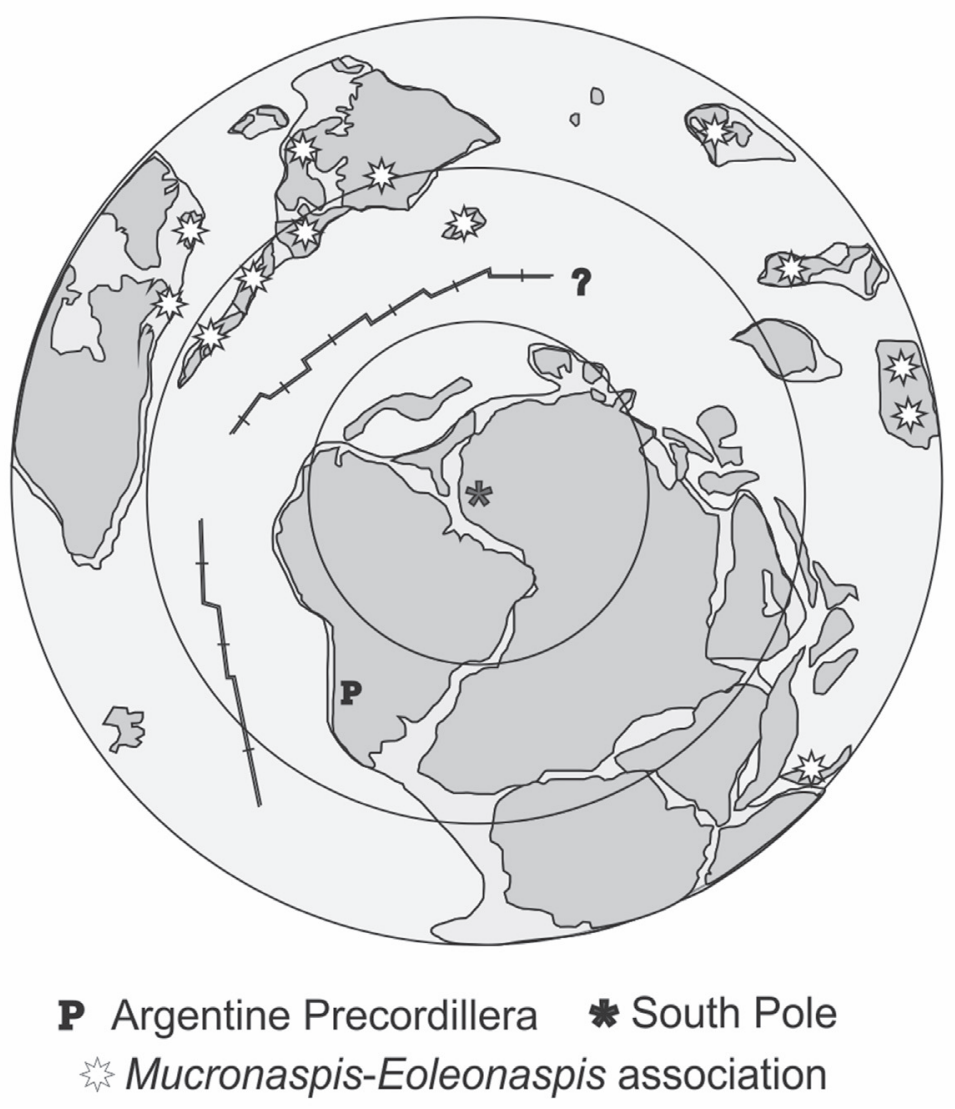

Figure 3. Paleogeographic reconstruction of the Late Ordovician (modified from Cocks \& Torsvik, 2002), showing the distribution of the Mucronaspis-Eoleonaspis association. Abbreviation: P, tentative record of Eoleonaspis in the Argentine Precordillera. 
Astini, R.A. \& Buggisch, W. 1993. Aspectos sedimentológicos y paleoambientales de los depósitos glacigénicos de la Formación Don Braulio, Ordovícico tardío de la Precordillera argentina. Revista de la Asociación Geológica Argentina, 48:217-232.

Baldis, B.A.; Beresi, M.S.; Bordonaro, O.L. \& Vaca, A. 1982. Síntesis evolutiva de la Precordillera Argentina. In: CONGRESO LATINOAMERICANO DE GEOLOGÍA, 5, 1982. Actas, Buenos Aires, p. 399-445.

Baldis, B.A. \& Blasco, G. 1975. Primeros trilobites ashgillianos del Ordovícico Sudamericano. In: CONGRESO ARGENTINO DE PALEONTOLOGÍA Y BIOESTRATIGRAFÍA, 1, 1975. Actas, Tucumán, p. 33-48.

Benedetto J.L. 1986. The first typical Hirnantia Fauna from South America (San Juan Province, Argentina Precordillera). Bioestratigraphie du Paleozoique, 4:439-447.

Benedetto, J.L. 2004. The allochthony of the Argentine Precordillera ten years later (1993-2003): a new paleobiogeographic test of the microcontinental model. Gondwana Research, 7:1027-1039. doi: 10.1016/S1342-937X(05)71082-0

Benedetto, J.L.; Halpern, K. \& Galeano Inchausti, J.C. 2013. High-latitude Hirnantian (latest Ordovician) brachiopods from the Eusebio Ayala Formation of Paraguay, Paraná Basin. Palaeontology, 56:61-78. doi:10.1111/j.14754983.2012.01158.x

Benedetto, J.L.; Sanchez, T.M.; Carrera, M.G.; Halpern, K. \& Bertero, V. 2011. Faunal shifts ad climatic changes in the Upper Ordovician of South America (West Gondwana). In: J.C. Gutiérrez Marco; I. Rábano \& D. García-Bellido (eds.) Ordovician of the World, Madrid, Instituto Geológico y Minero de España, p. 55-60 (Cuadernos del Museo Geominero 14).

Bengtson P. 1998. Open nomenclature. Palaeontology, 31:223-227

Bergström, S.M.; Chen, X.; Gutiérrez-Marco, J.C. \& Dronov, A. 2009. The new chronostratigraphic classification of the Ordovician System and its relations to major regional series and stages and to $\delta{ }^{13} \mathrm{C}$ chemostratigraphy. Lethaia, 42:97-107. doi:10.1111/j.1502-3931.2008.00136.x

Bertero, V. \& Halpern, K. 2012. Primer hallazgo de Holopea (Hall, 1847) (Gastropoda) en asociación con la fauna de braquiópodos hirnantianos de la Formación Don Braulio, Sierra de Villicum, Precordillera Argentina. Ameghiniana, 49:R42.

Budil, P.; Fatka, O.; Mergl, M. \& Martin, D. 2011. Trilobite biostratigraphy of the Králův Dvůr Formation (Upper Katian, Prague Basin Czech Republic): global faunal changes or facies-related distribution? Geologické výzkumy na Moravě a ve Slezsku, 18:4-10.

Carrera, M. \& Halpern, K. 2011. A post-glacial bryozoan fauna from the Upper Ordovician (Hirnantian) of the Argentine Precordillera In: J.C. Gutiérrez Marco; I. Rábano \& D. García-Bellido (eds.) Ordovician of the World, Madri, Instituto Geológico y Minero de España, p. 89-94 (Cuadernos del Museo Geominero 14).

Chen, X.; Rong, J-Y.; Fan, J.; Zhan, R. \& Mitchell, C.E. 2003. The global boundary stratotype section and point (GSSP) for the base of the Hirnantian Stage (the uppermost of the Ordovician System). Episodes, 29:183-196.

Cocks, L.R.M. \& Cooper, R.A. 2004. Late Ordovician (Hirnantian) shelly fossils from New Zealand and their significance. New Zealand Journal of Geology and Geophysics, 47:71-80. doi:10.1080/00288306.2004.9515038

Cocks, L.R.M. \& Fortey, R.A. 2002. The palaeogeographical significance of the latest Ordovician fauna from the Panghsa-Pye Formation of Burma. Special Papers in Palaeontology, 67:57-76.
Cocks, L.R.M. \& Torsvik, T.H. 2002. Earth geography from 500 to 400 million years ago: a faunal and palaeomagnetic review. Journal of the Geological Society, 159:631-644. doi: 10.1144/0016-764901-118

Congreve, C.R. \& Lieberman B.S. 2008. Phylogenetic and biogeographic analysis of Ordovician homalonotid trilobites. The Open Paleontology Journal, 1:24-32. doi:10.1371/journal. pone.0021304

Congreve, C.R. \& Lieberman B.S. 2010. Phylogenetic and biogeographic analysis of Deiphonine trilobites. Journal of Paleontology, 84:128-136. doi:10.1666/09-026.1

Congreve, C.R. \& Lieberman B.S. 2011. Phylogenetic and biogeographic analysis of Sphaerexochine trilobites. PloS One, 6:e21304. doi:10.1371/journal.pone.0021304

Curtis, N.J. \& Lane, P.D. 1998. The Llandovery Trilobites of England and Wales. London, Palaeontographical Society, p. 51-101 (Monographs 2).

Lespérance, P.J. 1988. Trilobites. Bulletin of the British Museum, Geology Series, 43:359-376.

Lespérance, P.J. \& Weissenberger, J.A.W. 1998. Trilobites of the Pabos Formation (Ashgillian, Upper Ordovician), Percé area, Quebec. Journal of Paleontology, 72:303-316.

Mergl, M. 2011. Earliest occurrence of the Hirnantia Fauna in the Prague Basin (Czech Republic). Bulletin of Geosciences, 86:63-70.

Owen, A.W. 1986. The uppermost Ordovician (Hirnantian) trilobites of Girvan, SW Scotland with a review of coeval trilobite faunas. Transactions of the Royal Society of Edinburgh: Earth Sciences, 77:231-239. doi: 10.1017/S0263593300010865

Owen, A.W.; Harper, D.A.T. \& Rong, J.Y. 1991. Hirnantian trilobites and Brachiopods in space and time. In: C.R. Barnes \& S.H. Williams (eds.) Advances in Ordovician Geology, Geological Survey of Canada, p. 179-190.

Peralta, S.H. \& Carter, C.H. 1990. La glaciación gondwánica del Ordovícico tardío: evidencias en fangolitas guijarrosas de la Precordillera de San Juan, Argentina. In: CONGRESO GEOLÓGICO ARGENTINO, 11, 1990. Actas, San Juan. p. 181-185.

Ramskold, L. \& Chatterton, B.D.E. 1991. Revision and subdivision of the polyphyletic 'Leonaspis' (Trilobita). Transactions of the Royal Society of Edinburgh: Earth Sciences, 82:333-371. doi: $10.1017 /$ S026359330000420X

Rong, J.Y. \& Harper, D.A.T. 1988. A global analysis of the latest Ordovician Hirnantian brachiopod faunas. Transactions of the Royal Society of Edinburgh: Earth Sciences, 79:383-402. doi: 10.1017/S026359330001436X

Rong, J.Y.; Huang, B.; Zhan, R.B. \& Harper, D.A.T. 2008. Latest Ordovician brachiopod and trilobite assemblage from Yuhang, northern Zhejiang, East China: a window on Hirnantian deep-water benthos. Historical Biology, 20:137-148. doi: 10.1080/08912960701673944

Sánchez, T.M.; Benedetto, J.L. \& Brussa. 1991. The late Ordovician stratigraphy, paleoecology and sea level changes in the Argentine Precordillera. In: C.R. Barnes \& S.H. Williams (eds.) Advances in Ordovician Geology, Geological Survey of Canada, p. 245-258.

Shaw, F.C. 2000. Trilobites of the Králův Dvůr Formation (Ordovician) of the Prague Basin, Czech Republic. Bulletin of Geosciences, 75:371-404.

Sheng, X.F. 1974. Classification and Correlation of Chinese Ordovician Series. Beijing, Earth Science Publishing House, $152 \mathrm{p}$. 
Šnajdr, M. 1984. Ǒceských trilobitech z rodu Orphanas-pis, Selnopleltoides a Taemaspis (Odontopleuridae). Ústřední Ústav Geologický Ústřední Praha, 153:212-216.

Storch, P. \& Mergl, M. 1989. Kralodvor-Kosov boundary and the late Ordovician environmental changes. Sbornik Geologických Véd, 44:117-153.

Toro, B.A. \& Brussa, E.D. 2003. Graptolites. In: J.L. Benedetto (ed.) Ordovician Fossils of Argentina, Secretaría de Ciencia y Tecnología/Universidad Nacional de Córdoba, p. 441-505.

Vaněk, J. \& Valíček, J. 2001. New index of the genera, subgenera, and species of Barrandian trilobites. Part A-B (Cambrian and Ordovician). Palaeontologia Bohemiae, 7:1-49.

Waisfeld, B.G. \& Vaccari, N.E. 2003. Trilobites. In: J.L. Benedetto (ed.) Ordovician Fossils of Argentina, Secretaría de Ciencia y Tecnología/Universidad Nacional de Córdoba, p. 295-410.
Wright, A.D. 1968. A westward extension of the upper Ashgillian Hirnantia Fauna. Lethaia, 1:352-367. doi: 10.1111/j.15023931.1968.tb01626.x

Zhan, R.B. \& Jin, J. 2007. Ordovician-Early Silurian (Llandovery) stratigraphy and palaeontology of the upper Yangtze platform, South China. Beijing, Science Press, 169 p.

Zhou, Z.; Zhou, Z. \& Yuan, W. 2012. Late Ordovician (Hirnantian) Mucronaspis (Songxites) dominant trilobite fauna from northwestern Zhejiang, China. Memoirs of the Association of Australasian Palaeontologists, 42:75-92.

Received in September, 2013; accepted in February, 2014. 